\title{
MODELING GROUP RAPPORTS IN OUTDOOR EDUCATION ACTIVITIES
}

\author{
Moldovan Elena ${ }^{1 *}$ \\ 1"Transilvania" University of Brașov, 1, Colina, Romania
}

Keywords: modeling, group relationships, free time activities

\begin{abstract}
Within the educational system, the outdoor activities are found in a broader spectrum introducing other parameters, indicators and referential frameworks in appreciating the formative act, thus constituting the non-institutionalized way of shaping education. The context of this type of study and investigation is the social one expressing the degree of socializing. The scientific analysis of certain elements of dynamic structures undergone by the group doing the outdoor activities has ensured the accomplishment of this purpose which has been done by successfully practicing the sociometrical method. One has used the sociometrical test that allows the determination of the way in which relationships manifest themselves inside the group of research implicitly influencing the degree of cohesion of the group and its organization. The objective of the research is to evaluate the development of the social climate by determining the existent inter personal relationships - affective and sympathetic - between students undergoing “Outdoor Education” activities.
\end{abstract}

\section{Introduction}

This paper presents a study regarding the modelling of group relationships through outdoor education activities. The paper is a formative endeavour for developing the individual's personality having as a main purpose the approach of an active education perspective by promoting outdoor education activities.

The man's forming process is complex and delicate and it is done throughout life. To educate, to culture the individual with the exigencies of contemporaneity presumes the commitment in an organized, conscious, orientated and systematized activity towards a purpose adequate to the moment (Antonesei, 1996).

The human being is a conscious and systematic receptor of formative factors through formal education, the latter having also incorporated sportive and corporal activities specific to these factors. Besides these classical formal frameworks man continues the reception and assimilation of these influential factors even in his free time through his non formal environment. Becoming a modern man requires a whole formation through his multiple physical,

\footnotetext{
*E-mail: e.moldovan@unitbv.ro
} 
intellectual, ethical and esthetical aspects, in a tight bond with the requirements of the contemporaneous and future world according to the real abilities through which he harmoniously develops his personality traits (Cucos, 2002).

From the socializing point of view though, E. Durkheim, considered the father of educational sociology, considered that education is "the methodical socializing of the younger generation; it is the action done by the adult generations on the ones that are not fully mature for the social life yet" concluding that "the purpose of education is to socialize the biologic individual through the construct of his social being that can overlap the individual one" (Durkheim, 1980). The sociology proposed by Durkheim is a social educative program, a pedagogical sociology that is done on the idea that education is a signally social thing; in each person there are two beings: an individual and a social one, and the "purpose of education is none other than constituting in each and every one of us this social being”.

The outdoor education activities represent a necessary ambient that generates and stimulates the formation and expression of behaviours apt to capitalize to the maximum the talents, skills and human values. However, these processes end successfully for the subjects only through a performing educational management, based on outdoor education activities that combine basic stimuli for activating and cultivating the skill resources. The behaviour, aspirations and successes of those practicing outdoor education activities can be positive if they can produce, and fulfil personal accomplishments and satisfactions within groups.

Outdoor education activities, through its means and methods, go after the following objectives:

- To Cultivate certain social attitudes and behaviors;

- To efficiently capitalize free time;

The old Socratic dictum claiming that "science without consciousness means nothing but ruins of the soul" is still valid today with the specification that besides science, ethics and morals are generally the pylons of human conduct. This due to the fact that, even though each value is unique through its specific acting domain, it is interdependent with the other social and human values.

The social behavior is done depending on the expectations and reactions of others. It is acquired in the socializing process or in special situations, the behavior implying an intellectual, structural, intentional and emotional component and can be opened and apt for becoming better, or closed, as in stereotypes (Schiopu, 1997).

\section{Material and methods}

The premises of the research, Outdoor education activities are activities with a social character always inviting us to communicate and interact and enabling us to develop social skills as well as specific attitudes. 
As a favorable environment to socializing, outdoor education activities have the following characteristics:

- They offer the chance to meet and communicate with other people, to acquire certain social skills such as tolerance and respect towards others, to live emotions not otherwise felt in other spheres of life, to adapt to the team's objective through cooperation and cohesion;

- The main purpose of practicing outdoor education activities is to support the free association of social contacts;

- The means used in these activities have a positive effect on selfappreciation, self-esteem, energy, disposition and wellbeing;

- They have positive effect on disabled people and other special categories of population;

- They represent a defined social field, governed by relatively strict rules and reglementation norms of sanctioning and highlighting the deviant behavior;

- They offer a way of more pronounced, experiential and applicative way of learning.

The effects of socializing through outdoor education activities are appreciable especially in a sedentary society where too many people and inactive physically. Such effects have a meaning for they make the individuals, eager and willing, to participate to the experimentation of certain situations close to reality with a lot of challenges regarding the personal and interpersonal development. The factors that contribute to a healthy socializing experience are: the orientation towards the task not the outcome, the acknowledgement of the purpose of the simple or complex actions and tasks and a long term perspective of modeling the group rapports (Holban, 1970).

The presence of solving certain tasks through games, through their specific that implies respecting a certain rules system, all of this creates the premises for shaping a group relationship.

In the process of socializing, the formed groups experiment new types of relationships, freer and more equal, not subdued to the parental control, qualitative more different than the family environment. The interactions that take place within these groups start to structure the individual's personality even from the early ages.

Through the group, the youngster makes contact with the interpersonal authority (Carcea, 2003). In a group, the individual learns to obey the groups' rules, to assume the role of empire in certain games forming a personal system of faiths regarding the concepts of justice, time and ability to cooperate. In comparison with every other factor of socializing, the groups have a system on rewards and punishments, approvals and disapprovals through which they constrain the members to conformity or non-conformity.

The sociology studies offer us interesting ideas regarding the way in which outdoor education activities can influence interpersonal relationships in a group. The research started from the idea that the social climate in a group can be determined by the activities done by the youngsters within this group. 
The purpose of the research has been to find certain outdoor education activities and efficient means of modeling the students' group rapports.

The objective of the research has been evaluating the group cohesion between the members of the III year students group (12 students) from the Physical Education and Mountainous sports Faculty. "Free time activities" discipline.

The objectives of the research:

1. Creating a group with high cohesion using the following?

- transforming the group in a team;

- encouraging members to organize themselves;

- choosing certain outdoor education activities that can offer them satisfaction;

- doing certain activities that allow group cohesion;

- experimentally checking the efficiency of outdoor education activities in guiding the process to improving the group cohesion;

- engaging the subjects in the experiment by applying the sociometrical matrix having at the core the 6 questions enquiry.

The hypothesis of the research: it goes from the premise that elaborating and applying the adapted content of certain efficient means and systems within outdoor education activities can influence the shaping of group rapports expressed through the group cohesion indicators.

The independent variable is that system of means and methods that targets mainly the inter human relationships within the student group, stimulating mutual collaboration.

The dependent variable has been represented by the results ensured by the utilization of the independent variable, and in the present research one has used the indicators showing exactly this group cohesion.

Action means

- Presenting the program, clarifying the expectations and fears; presenting the rules and signing the educational course contract; Presentation: "KOLB" learning cycle.

- Models of experiential learning; Comfort zone;

- Safety and risk management;

- Establishing practical and educational objectives;

- Simple interactive activities: games of knowing each other. Introductive activities of solving problems

- Exercises of acceptance, taking responsibility and supporting the team mates - debating and analyzing the lived experienced;

- Skipping rope - debating and analyzing the lived experience;

- Aladdin's mat - debating and analyzing the lived experience;

- The Chain - debating and analyzing the lived experience;

- Transport based on trust - debating and analyzing the lived experience.

- Hiking: school of nature, contemplating nature, observing the environment and following the route and the phenomena of nature. 
- Participating, during the hike, to an ecological project, based on the characteristics of the environment. "You learn in nature and from nature".

Activities with solving complex tasks

- Transporting certain objects on a difficult route in the woods debating and analyzing the lived experience;

- Building a bridge - thorough execution through learning - debating and analyzing the lived experience;

The sociometrical method uses as a basic tool the enquiry technique - or the so-called sociometrical test. The chatacteristics of this method, different of other research methods, are the content of the questions, the way they are dealt with as well as the way answers are handled. The most important way of discovering the diverse traits specific to the group is the analysis of preferential relationships manifested between members, relationships that appear spontaneous, thus being caused by the social conditions of formation and development, besides the specific individual factors (Moreno, J., 1973) Through the sociometrical matrix, one has established the group

\section{Results and Discussions}

The essential component of the sociometrical test is represented by the preference or the choice that can be positive, negative or indifferent being expressed as one of the possible answers given by the subjects to the questions posed by the researcher. The students were asked to choose as many names as they liked and to specify the colleagues they like in different situations and the ones they reject. Based on the answers to the sociological enquiry, one has established the sociometrical matrix and based on the preferential values one has calculated the group cohesion. Knowing the values of the cohesion indicator takes into account also the total value of the preferences as well as the total values of the rejections from the sociometrical matrix, which allows the calculation of the respective indicator.

To the initial testing, based on the sociometrical matrix for the investigated group of students, the group cohesion is $\mathrm{Cgr}=0,06$, and to the final testing Cgr=0,22. After C. Matei' s table (1981) the group of students progressed from a group with a weak cohesion to a group with a small cohesion, the difference between the initial and final testing being significant.

Taking into account the fact that the experiment approached social aspects, one has established as a level of rejection of the null hypothesis the threshold of $p<0,05$. One has presumed that the group of students will progress more. Using this threshold, the probability that the results be by chance is less than $5 \%$. This is an acceptable value in social sciences.

Knowing the comparative results between the initial and final testing has allowed the estimation of the group's evolution. Thus, one has discovered the progress made by the group of students after undergoing the "Free time 
activities" discipline with the purpose of highlighting the influence of group rapport on outdoor education activities.

The results of the date from the sociometrical matrix to the initial testing after applying the group cohesion calculation method:

$$
\mathrm{C} \text { gr }=\frac{\sum \mathrm{p}-\sum \mathrm{r}}{\sum p+\sum r}=\frac{89-78}{89+78}=\frac{11}{167}=0,06
$$

The results of the data from the sociometrical matrix to the final testing :

$$
\mathrm{C} \text { gr }=\frac{\sum \mathrm{p}-\sum \mathrm{r}}{\sum p+\sum r}=\frac{175-110}{175+110}=\frac{65}{285}=0,22
$$

Table 1 The value dynamics of the group cohesion

\begin{tabular}{|l|c|c|}
\hline \multirow{4}{*}{ Nr.crt } & \multicolumn{2}{|c|}{ Group Cohesion - C gr. } \\
\cline { 2 - 3 } & Initial testing & Final testing \\
\cline { 2 - 3 } & $\mathbf{0 , 0 6}$ & $\mathbf{0 , 2 2}$ \\
\hline
\end{tabular}

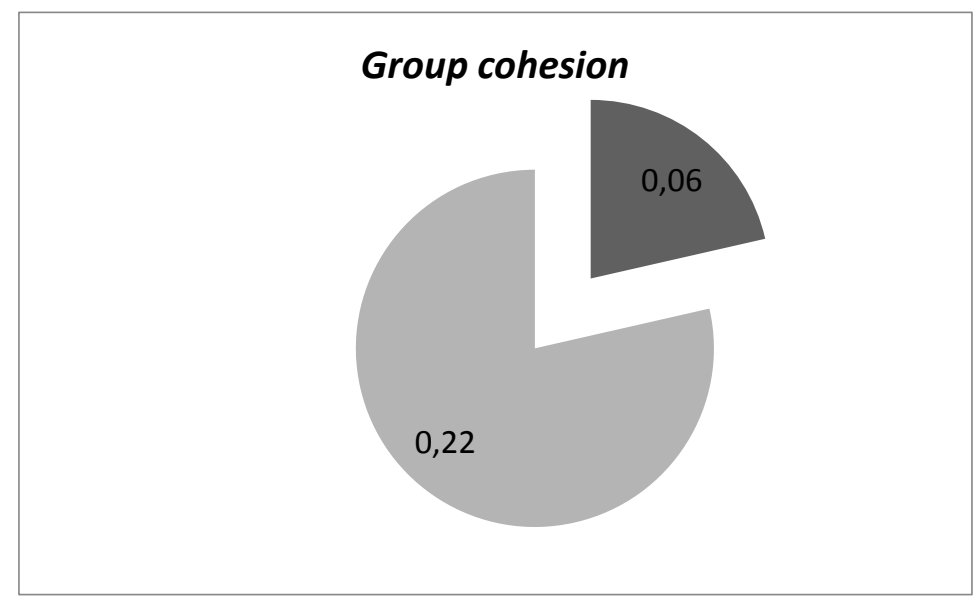

Figure 1. The value dynamics of the group cohesion indicator

The cohesion indicator (Tab. 1 and Fig. 1) expresses the de facto growth thus the improvement of the group cohesion showing a superior degree of student maturity that have been involved regularly and disciplined to all the practical assignments.

To this evaluation, one can notice that the group has evolved from a weak cohesion group to a small cohesion group which proves that after an academic year one has seen an improvement in group rapports. 
The cohesion indicator shows a stage a visible improvement of the group cohesion thus claiming the more pronounced maturity and growth of the student group that has participated to all the practiced actions within the researched outdoor education system.

\section{Conclusions}

The obtained results give us the right to say that the hypothesis has been confirmed to what modeling the group rapports through outdoor education activities is concerned, observing the following:

- They were adapted to her individual characteristics, these making possible obtaining certain very precise information regarding the beneficial progress of group rapports, through the obtained results in marking the positive choice options more to the final testing;

- We notice the decrease of the rejection option much less visible to the final testing which has led to the group cohesion.

The methodological framework of outdoor education activities has offered an integral and dynamic image on the modeling of group rapports and also on forming the social behavior and cohesion determining the improvement within the social interaction abilities as well as in group of each and every participant in a better position.

The sociometrical tests applied on the group having as a purpose the establishment of the group cohesion, have highlighted significant differences between the initial and final testing. Examining the better results shown in the final testing one can conclude that these are due to the fact that during the outdoor education activities the students have been continuously motivated and encouraged to interact, to influence each other, becoming aware that they are seen and treated as a group. Following the behavioral observation method one can also conclude that these results are partially due to the suggestions presented in the outdoor education activities with the main objective of influencing socializing; one has also accomplished a positive influence on the group rapport to certain relational traits.

The approach of socializing through outdoor education activities requires a structural and functional innovation in the non-formal educative process, which also requires quite a lot of creativity and professionalism.

\section{References}

1. ANTONESEI, L. (2001). Paideea. Fundamentele culturale ale educaţiei, Iași: Polirom;

2. CARCEA, M.I. (2003). Cunoaşterea psihopedagogică a persoanei. Manual de invăţare autonomă instituţional asistată, Iaşi: Gh. Asachi;

3. CUCOŞ, C. (2002). Timp şi temporalitate în educaţie. Elemente pentru un management al timpului şcolar, Iaşi:Polirom; 
4. DURKEIM, E. (1980). Educaţie și sociologie, Bucureşti: Didactică și Pedagogică;

5. HOLBAN I. (1970). Testul sociometric de personalitate, uz intern, Metodologia diagnosticului psihopedagogic, Iaşi: Institutul de ştiinţe pedagogice;

6. MATEI, N.C. (1981). Psihologia relaţiilor morale interpersonale, Bucureşti: Scrisul românesc, p 89;

7. MORENO, J. (1935). Who Shall Survive ?, New York, Beacon House;

8. ȘCHIOPU, U. (1997). Dicționar enciclopedic de psihologie, București: Babel.

\title{
MODELAREA RAPORTURILOR DE GRUP IN ACTIVITATILE DE OUTDOOR EDUCATION
}

\author{
Moldovan Elena ${ }^{1}$ \\ ${ }^{1}$ Universitatea Transilvania din Brașov, Strada Colinei nr.1, Romania
}

Cuvinte cheie: modelare, relatii de grup, activități de timp liber

\section{Rezumat}

Contextul acestui tip de studii și investigații este cel social exprimând gradul socializării. Cercetarea a pornit de la ideea că climatul social este determinat de nivelul de socializare. Analiza științifică a unor elemente de structuri dinamice ale grupurilor derulînd activitatile de outdoor education, a asigurat indeplinirea scopului cercetării ceea ce s-a realizat prin practicarea cu succes a metodei sociometrice. S-a utilizat testul sociometric care permite determinarea modului în care se manifestă în realitate, relaţiile în cadrul grupului supus cercetării, acestea influenţând implicit gradul de coeziune a grupului, organizarea internă a acestuia. Cercetarea are ca obiectiv evaluarea dezvoltării climatului social prin determinarea relaţiilor interpersonale afectiv-simpatetice existente între studenti în cadrul activităţilor de „Outdoor education”.

\section{Introducere}

In lucrarea de fata este prezentat un studiu privind modelarea raporturilor de grup prin activităţi de outdoor education. Lucrarea este un demers formativ pentru dezvoltarea personalităţii individului, având ca obiectiv principal abordarea unei perspective acţionale de educare a tinerei generaţii prin promovarea activităţilor de outoot education.

Procesul de formare a omului este complex şi delicat, realizându-se pe tot parcursul vieţii. A educa, a înălţa, a realiza omul cultivat, cu exigenţele impuse de contemporaneitate, presupune angajarea într-o activitate conştientă, organizată, sistematizată şi orientată spre finalităţi adecvate realităţii momentului( Antonesei, 1996). 
Ființa umană e un receptor conștient și sistematic de factori formativi, prin educația formală, aceasta avînd încorporate și activități corporale și sportive specifice acestor factori. Dincolo de aceste cadre formale clasice omul continuă receptarea și prelucrarea acestor factori de influență în timpul său liber prin mediul nonformal.

Atingerea calitătii omului modern necesită formarea lui deplină sub multiplele sale aspecte fizice, intelectuale, etice, estetice, în strănsă legătură cu cerințele complexe ale lumii contemporane şi a celei viitoare, conform competențelor reale, prin formarea cărora se dezvoltă armonios trăsăturile de personalitate ale oamenilor (Cucoş, 2002).

Din punct de vedere al socializării, Durkheim, 1980, a considerat părintele sociologiei educaţiei consideră că educaţia este ,socializarea metodică a tinerei generaţii; este acţiunea exercitată de către generaţiile adulte asupra celor care nu sunt coapte încă pentru viaţa socială" considerând că ,scopul educaţiei este de a socializa individul biologic prin construirea fiinţei sale sociale care să se suprapună celei individuale”.

Sociologia propusă de Durkheim este un program social educativ, o pedagogie sociologică care se întemeiază pe ideea că educaţia este un lucru cu deosebire social; în fiecare om sunt două fiinţe:una individuală şi una socială, iar „scopul educaţiei nu este altul decât a constitui în fiecare din noi această fiinţă socială". Domeniul activităților de outdoor education reprezintă un ambient necesar ce generează și stimulează formarea ca și exprimarea conduitelor apte să valorifice la maximum talentele, aptitudinile și valorile umane. Insă aceste procese se încheie benefic pentru subiecți numai printr-un management educațional performant, bazat pe activități de outdoor education care îmbină stimuli de bază pentru activarea şi cultivarea resurselor aptitudinale.

Comportamentul, aspiraţiile şi reuşitele celor care practică activităţile de outdoor education vor fi pozitive dacă acestea vor produce împlini, satisfacţii și reușite personale în cadrul grupurilor. Activitățile de outdoor education, prin metodele şi mijloacele de care dispune, urmăresc realizarea următoarelor obiective:

- cultivarea unor atitudini şi comportamente sociale;

- valorificarea eficientă a timpului liber.

Vechiul dicton socratic afirmînd că ,ştiinţa fără conştiinţă nu înseamnă decât ruină a sufletului”, e valabil și azi cu precizarea că pe lîngă știință și etica, morala în general sunt piloni ai conduitei umane. Aceasta datorită faptului că , deși fiecare valoare este unică prin specificul domeniului său de acțiune, ea este interdependentă cu celelalte valori socio-umane.

Comportamentul social se reglează în funcţie de aşteptările şi reacţiile celorlalţi. El se dobândeşte în procesul de socializare sau în situaţii special, comportamentul implică o componentă intelectuală, una structurală, una intenţională şi una emoţională şi poate fi deschis şi apt de perfecţionare, sau închis, stereotipizat (Şchiopu, 1997). 


\section{Material şi metode}

\section{Premisele cercetării}

Activitățile de outdoor education sunt activități cu caracter social care ne invită mereu la comunicare, interacţiune, determinându-ne să dezvoltăm deprinderi de relaţionare socială, precum şi atitudini specifice.

$\mathrm{Ca}$ mediu favorabil socializării, activitățile de outdoor education, au următoarele caracteristici:

- oferă o ocazie de a cunoaşte alţi oameni şi de a comunica cu ei, de a dobândi unele deprinderi sociale cum sunt toleranţa şi respectul faţă de ceilalţi, de a trăi emoţii nu prea uşor de resimţit în alte sfere ale vieţii, de adaptare la obiectivul echipei, prin cooperare şi coeziune;

- principalul ţel al practicării activităților de outdoor education este de a sprijini libera asociere în vederea contactelor sociale;

- mijloacele utilizate în carul acestor activităţi au efecte pozitive asupra autoaprecierii, încrederii în sine, energiei, dispoziţiei şi stării de bine;

- au efecte pozitive pentru persoanele cu handicap şi alte categorii speciale de populaţie;

- reprezintă un câmp social definit, guvernat de reguli relativ stricte şi de norme regulamentare de sancţionare a nonconformării la acestea şi de evidențiere a comportamentului deviant;

- oferă o modalitate de învăţare cu un mai pronunţat caracter experienţial, aplicativ.

Efectele socializării prin activități de outdoor education sunt de apreciat mai ales într-o societate sedentară, unde prea mulţi oameni sunt fizic inactivi. Asemenea efecte au şi o valoare în sine, căci îi fac pe indivizi, dornici și capabili să participe la experimentarea unor situații apropiate de realitate, cu foarte multe provocări privind dezvoltarea personală și interpersonală. Factorii care contribuie la o experiență de socializare sănătoasă sunt: orientarea către sarcina de îndeplinit nu către rezultat, conştientizarea scopurilor acțiunilor și sarcinilor simple sau complexe de realizat şi o perspectivă pe termen lung a modelării raporturilor de grup (Holban, 1971).

Prezenţa acțiunilor de rezolvare a unor sarcini precise prin joc, prin specificul lor ce implică respectarea unui sistem de reguli, subordonarea intereselor proprii celei de grup, creează premizele pentru formarea unor relaţii de grup. În procesul socializării individului, grupurile formate experimentează noi tipuri de relaţii, mai libere şi mai egalitare, nesupuse controlului parental, calitativ diferite celui din mediul familial. Interacţiunile care au loc în cadrul acestor grupuri încep să structureze personalitatea individului încă de la cele mai fragede vârste. Prin intermediul grupului, tânărul intră în contact cu autoritatea interpersonală (Carcea, 2003). Într-un grup, individul învaţă să se supună regulilor acestuia, să-şi asume rolul de arbitru în unele jocuri, formându-şi şi un sistem personal de credinţe referitoare la conceptele de dreptate, formându-se în acelaşi timp şi disponibilitatea de a coopera. În raport cu orice alt factor al 
socializării grupurile dispun de un sistem de recompense şi pedepse, de aprobări şi dezaprobări prin care îşi constrânge membrii la constrângere şi conformitate.

Studiile de sociologie ne oferă idei interesante privind modul în care activităţile de outdoor education pot influenţa relaţiile interpersonale în interiorul unui grup. Cercetarea a pornit de la ideea că, climatul social într-un grup pot fi determinate de activităţile pe care le derulează tinerii.

Scopul cercetării de faţă a fost găsirea unor activităţi de outdor education şi modalități eficiente de modelare a raporturilor de grup a studenților.

Cercetarea a avut ca obiectiv evaluarea coeziunii de grup existente între componenţii grupului de studenţi din anul III (numărul studenţilor implicaţi în cercetare a fost de 12), din cadrul Facultăți de Educație Fizică și Sporturi Montane, la disciplina "Activități de timp liber".

Obiectivele cercetării:

1. Crearea unui grup cu coeziune ridicată utilizând următoarele mijloace:

- transformarea grupului într-o echipă;

- Încurajarea membrilor grupului de a se organiza singuri;

- alegerea unor forme de activităţi de outdoor education care să le ofere satisfacție;

- derularea unor activitătii care să permită dezvoltare coeziunii de grup;

- verificarea experimentală a eficienţei activităţilor de outdoor education în dirijarea procesului de îmbunătăţirii al coeziunii de grup al studenților;

- angrenarea subiecţilor în experiment prin aplicarea matricei sociometrice având la bază chestionarul compus din 6 întrebări.

Ipoteza cercetării: se pleacă de la premisa că elaborarea şi aplicarea conţinutului adaptat a unor mijloace și sisteme de acţionare eficiente în cadrul activităților de outdoor education, la studenți, se va putea influența modelarea raporturilor de grup exprimate prin îmbunătăţirea indicatorilor coeziunii de grup.

Variabila independentă a constat din acel sistem de metode şi mijloace de acţionare care au vizat în principal relaţiile interumane din cadrul grupei de studenţi, stimulând colaborarea între ei.

Variabila dependentă a fost reprezentată de rezultatele asigurate prin utilizarea variabilei independente, iar în prezenta cercetare, au fost folosiţi indicatorii, evidențiind coeziunea grupului analizat.

\section{Mijloace de acționare}

- Prezentarea programului, clarificarea aşteptărilor şi temerilor; prezentarea regulilor şi semnarea contractului educaţional de curs.

- Prezentarea: ciclul de învăţare „KOLB”;

- Modele de învăţare experienţiale; Zona de confort;

- Managementul riscului şi siguranţei;

- Stabilirea obiectivelor educaţionale şi de practică;

- Activităţi interactve simple: jocuri de cunoaştere.

Activităţi introductive de rezolvare a problemelor:

- Exerciţii pentru acceptarea, asumarea responsabilităţilor şi sprijinul colegilor de echipă - dezbaterea şi analiza propriilor experienţe trăite. 
- Coarda - dezbaterea şi analiza propriilor experienţe trăite.

- Covorul lui Aladin - dezbaterea şi analiza propriilor experienţe trăite.

- Lanţul - dezbaterea şi analiza propriilor experienţe trăite .

- Transportul pe bază de încredere - dezbaterea şi analiza propriilor experienţe trăite.

Drumeţie: Şcoala naturii, contemplarea naturii, observarea mediului şi urmărirea traseului şi a fenomenelor care au loc în natură.

- Participarea în cadrul drumeţiei la realizarea unui proiect ecologic, bazat pe caracteristicele mediului înconjurător. „Înveţi în natură şi de la natură”.

Activităţi cu rezolvarea unor sarcini complexe:

- Transportul unor obiecte pe un traseu dificil în padure - dezbaterea şi analiza propriilor experienţe trăite.

- Construirea unui pod- execuţie minuţioasă prin proiecte de învăţare.dezbaterea şi analiza propriilor experienţe trăite.

Metoda sociometrică utilizează ca instrument de bază tehnica chestionarului - sau aşa numitul test sociometric. Caracteristicile acestei metode, care o deosebesc de alte metode de cercetare, le reprezintă în ordine conţinutul întrebărilor, modul lor de administrare ca şi felul de prelucrare a răspunsurilor.

Mijlocul cel mai important de decelare, de aflare a diverselor trăsături specifice ale grupului e analiza relaţiilor preferenţiale manifestate între membrii acestuia, relaţii care apar în mod spontan, ele fiind însă cauzate de fapt, pe lângă factorii specific individuali, de condiţiile sociale ale formării-dezvoltării membrilor componenți ai grupului analizat (Moreno, 1973). Prin intermediul matricei sociometrice, s-a stabilit în final coeziunea grupului.

\section{Rezultate şi discuţii}

Componenta esențială a testului sociometric o reprezintă preferinţa sau alegerea care poate fi pozitivă, negativă sau indiferentă, fiind exprimată ca unul dintre răspunsurile posibile date de subiecți la întrebările puse de cercetător.

Studenților li s-a cerut să aleagă oricâte nume doresc şi să specifice pe colegii pe care-i preferă în diferite situaţii şi pe cei pe care-i resping. Pe baza răspunsurilor la chestionarul sociologic, s-a realizat matricea sociometrică şi pe baza valorilor tuturor preferinţelor şi respingerilor obţinute, s-a calculat indicele de coeziune de grup. Aflarea valorii indicelui de coeziune ia în calcul atât valoarea totală a preferinţelor cît şi valoarea totală a respingerilor din matricea sociometrică, ceea ce permite calcularea indicatorului respectiv.

La testarea iniţială, în urma studierii matricei sociometrice la grupa de studenţi investigată indicele coeziunii de grup are valoarea de $\mathrm{Cgr}=0,06$, la testarea finală valoarea indicelui de coeziune este $\mathrm{Cgr}=0,22$. După tabelului lui Matei, 1981 grupa de studenți a progresat de la grup cu coeziune slabă la grup cu coeziune mică, diferenţa dintre testul final şi cel iniţial fiind seminificativ. 
Având în vedere că experimentul a abordat aspecte sociale, s-a stabilit drept nivel de respingere a ipotezei nule pragul de $\mathrm{p}<0,05$. S-a presupus că grupul de studenți va progresa mai mult. Utilizând acest prag, probabilitatea ca rezultatele să se datoreze întâmplării este mai mică de 5\%. Aceasta este o valoare acceptabilă în ştiinţele sociale

Aflarea rezultatelor comparative între testările iniţiale şi cele finale, a permis estimarea evoluţiei grupului. În acest fel s-a putut cunoaşte nivelul progresului înregistrat de grupul de studenți, după parcurgerea programei la disciplina "Activități de timp liber" având ca principal scop, în cazul studiului de față, evidențierea influențării raportului de grup prin activități de outdoor education.

Rezultatele conform datelor din matricea sociometrică la testarea inițială dupa aplicarea frolei de calcul a coeziunii de grup:

$$
\mathrm{C} \text { gr }=\frac{\sum \mathrm{p}-\sum \mathrm{r}}{\sum p+\sum r}=\frac{89-78}{89+78}=\frac{11}{167}=0,06
$$

Rezultatele conform datelor din matricea sociometrică la testarea finală:

$$
\mathrm{C} \mathrm{gr}=\frac{\sum \mathrm{p}-\sum \mathrm{r}}{\sum p+\sum r}=\frac{175-110}{175+110}=\frac{65}{285}=0,22
$$

Tabel 1 Dinamica valorilor coeziunii de grup

\begin{tabular}{|c|c|c|}
\hline \multirow{2}{*}{$\begin{array}{l}\text { Nr. } \\
\text { crt }\end{array}$} & \multicolumn{2}{|c|}{ Coeziunea de grup - C gr. } \\
\cline { 2 - 3 } & Testare inițială & Testare finală \\
\hline
\end{tabular}

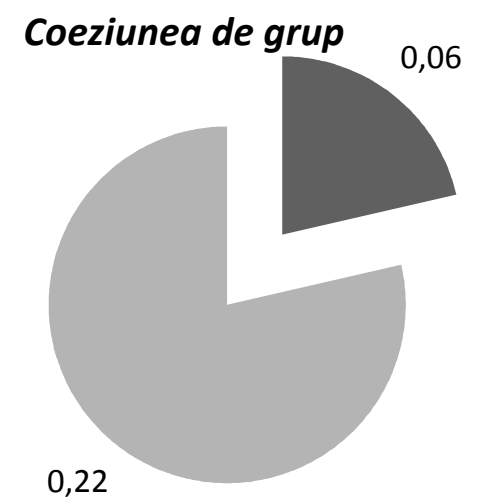

Figura 1. Dinamica rezultatelor valorii indicatorului coeziunii de grup 
Indicele de coeziune conform (Tab. 1 şi Fig. 1) exprimă creșterea de facto, deci ameliorarea coeziunii de grup arătînd astfel un grad superior de maturizare a studenţilor care s-au implicat regulat şi disciplinat la toate lucrările practice. La această evaluare, se poate constat ca grupa a evoluat de la un grup cu coeziune slabă la un grup cu coeziune mică, ceea ce demonstrează ca după un an universitar s-a realizat o îmbunătăţire privind raporturile de grup. Indicele de coeziune arată deci o etapă de ameliorare vizibilă a coeziunii de grup precizând astfel maturizarea mai accentuată şi creșterea identităţii grupului de studenţi care a participat la toate acțiunile practicate în sistemul de outdoor education ce a fost cercetat.

\section{Concluzii}

Rezultatele obţinute în studiul de faşă, ne dau dreptul să afirmăm că ipoteza s-a confirmat în ceea ce privește modelarea raportului de grup prin activităţi de outdoor education și putem constata următoarele:

- au fost adaptate la particularităţile individuale, acestea făcând posibile, obţinerea unor informaţii foarte precise în legătură cu progresul raporturilor de grup, benefice, prin rezultatele obținute în marcarea opțiunilor de alegere pozitivă mult mai mare la testarea finală;

- remarcăm micșorarea opțiunii de respingere a colegilor mult mai mică la testarea finală ceea ce a dus la creșterea coeziunii de grup.

Cadrul metodologic de desfasşurare a activităților de outdoor education a oferit o imagine integral-dinamică asupra modelării raporturilor de grup dar și asupra formării comportamentului şi coeziunii sociale a grupei supuse cercetării, determinând îmbunătăţirea în cadrul capacităţilor de interacţiune socială, precum şi situarea în grupă, a fiecărui participant într-o poziţie mai bună.

Testările sociometrice aplicate asupra grupei având ca scop stabilirea coeziunii sociale au scos în evidenţă diferenţe semnificative între testările iniţiale şi finale.

Examinând rezultatele mai bune obţinute la testarea finală, în urma aplicării metodei sociometrice, se poate concluziona că acestea se datorează faptului că, pe parcursul derulării activităților de outdoor education, studenții au fost motivaţi şi încurajaţi în permanenţă să interacţioneze, să se influenţeze reciproc, formându-li-se conştiinţa că sunt văzuţi şi trataţi ca un grup.

În urma utilizării metodei observaţiei comportamentale se poate concluziona că aceste rezultate se datorează în bună măsură sugestiilor prezentate în cadrul desfăşurării activităţilor de outdoor education cu obiectivul principal de influențare prin acestea a socializării, s-a realizat o influenţă pozitivă a raportului de grup contribuind la formarea unor trăsături pozitive de relaționare.

Abordarea problematicii socializării prin intermediul activităţilor de outdoor education, necesită o inovare structural-funcţională, în procesul educativ non-fromal, ceea ce necesită foarte multă creativitate şi profesionalism. 